Journal of Animal and Veterinary Advances 11 (11): 1954-1964, 2012

ISSN: $1680-5593$

(C) Medwell Journals, 2012

\title{
DNA Based Diagnosis of Canine Bacterial Diseases
}

\author{
${ }^{1}$ Idress Hamad Attitalla and ${ }^{2}$ Mehmet Ozaslan \\ ${ }^{1}$ Department of Microbiology, Faculty of Science, Omar Al-Mukhatr University, \\ Box 919, Al-Bayda, Libya \\ ${ }^{2}$ Gaziantep Universitesi, Biyoloji Bolumu, 27310 Gaziantep, Turkey
}

\begin{abstract}
In current era pets are important part of the social life. Moreover, increased use of animal assisted therapies in treatment of people with special needs gives a glimpse of their beneficial role in future. Dogs are one of the commonly adopted animals as pet and more often develops an intimate relation with their owners. Hence, chances of disease transfer from dogs to humans are high. In this review some important bacterial diseases of dogs are discussed with respect to their DNA based diagnosis. PCR was found to be effective for detection of diseases in most of the cases. To distinguish between pathogenic and nonpathogenic strains of an organism, combination of PCR with other DNA based diagnostic techniques like Restriction Fragment Length Polymorphism (RFLP), found to be effective. In future continuous efforts are required to devise new methods for rapid detection of these pathogens.
\end{abstract}

Key words: Brucellosis, colibacillosis, giardiasis, Lyme, leptospirosis, salmonellosis, campylobacteriosis, urinary tract infection

\section{INTRODUCTION}

The relationship between humans and their animals is very old and these days pets are becoming more common at homes as a social substitute. Pets are more commonly associated with induction of well being in people and development of social skills in children. On an average about $62 \%$ of US households have a pet, which shows that these pets are integral part of the daily social life (APPA, 2011). People suffering with loneliness are often advised to adopt a pet to reduce the harmful effects of social loneliness. In addition to all these factors adaptation of animal assisted therapies in treatment of people with special needs results in elevated number of pets.

Increased number of pets in the daily life also increases the risk infections that are zoonotic in nature. Brucellosis is a common disease of animals (Abd El-Razik et al., 2007; Junaidu et al., 2006) and it is also reported in humans (Hedayatizadeh-Omran et al., 2010; Akhtar and Latif, 2000). Dirofilaria immitis, Ehrlichia canis and Borrelia burgdorferi are pathogens that are known for causing infections in both animals and humans (Melek et al., 2005; Karami et al., 2006; Ranjbar-Bahadori et al., 2007; Icen et al., 2011; Gholami et al., 2011). Echinococcosis is a common disease reported in various animals, it is also common in humans; Vahedi and Vahedi (2012) conducted a study in Iran to check its prevalence in humans, they concluded that this disease was mainly found in females (age 20-40). In addition, liver and lungs were found to be the major sites of infection. Influenza virus is known for causing infection in birds Majidzadeh et al. (2011), Farooq et al. (2006) and Hadipour (2011) has reported that poultry farm workers and veterinarians are highly prone to this disease. All these facts highlight the importance of proper detection and treatment of these animal diseases, not only for the improvement of animal health but also for humans' welfare.

Development of resistance in these pathogens against currently used antimicrobial drugs is a potential threat to human health (Moniri and Dastehgoli, 2007; Karou et al., 2009; Joseph et al., 2011; Mehrabian and Jaberi, 2007). The emergence rate of antimicrobial resistant pathogens is higher than the discovery of new drugs that are effective against these pathogens; this fact leads the scientists to find new sources for antifungal (Malabadi and Kumar, 2007; Karthishwaran and Mirunalini, 2010; Widodo et al., 2008; Hassan et al., 2007; Hadizadeh et al., 2009; Harun-Or-Rashid et al., 2006) antiviral (Sohail et al., $2011 \mathrm{a}, \mathrm{b}$; Vignesh et al., 2011; Momtaz and Abdollahi, 2010) and antibacterial agents (Jazani et al., 2008; Anam et al., 2010; Haque et al., 2009; Geidam et al., 2007; Manikandan et al., 2011; Motamedi et al., 2010). These days plants are under extensive research to identify new compounds that have

Corresponding Author: Mehmet Ozaslan, Gaziantep Universitesi, Biyoloji Bolumu, 27310 Gaziantep, Turkey 
potential medicinal properties (Karim et al., 2011; Sohail and Sohail, 2011; Sohail et al., $2011 \mathrm{c}$; Karim and Kanwal, 2011; Ahmida, 2011; Oyedemi et al., 2011; Iweala et al., 2011) and many potential antimicrobial compounds have been identified. However, suppression of factors that promote antimicrobial resistance will be helpful in delaying the emergence of antimicrobial resistance. Domestic animals that are taking antibiotics either directly or indirectly have been reported as a source of antibiotic resistant pathogens (Leonard et al., 2012; Ahmed et al., 2012). Early detection of pathogenic diseases will facilitate the effective control of pathogen and reduces the overuse of antibiotics. PCR is a good diagnostic technique for in time detection of diseases that are of zoonotic origin (Rahimi and Doosti, 2012). Researchers have conducted a literature review to highlight the importance of PCR in diagnosis of bacterial diseases of dogs, which are of zoonotic nature.

\section{BACTERIAL DISEASES IN DOGS}

Brucellosis: Brucellosis is a bacterial infection in animals, which is caused by a Gram-ve bacteria called Brucella canis (Moore, 1969). It is the most common zoonotic diseases, which was listed as a human affecting disease in the early 20 th century on Malta island and hence known as Malta fever. This disease can affect almost all domestic animals and it is more common in countries with poor standards of animal and public health programs (Capasso, 2002). Prevalence of this disease varies among animals, e.g., cattle $(0.85-23.3 \%)$, buffaloes (4.2-10\%) camels $(0.0-17.20 \%)$, goat $(0.86-12 \%)$ and many others (Ahmed and Munir, 1995; Refai, 1989; Memish, 2001; El-Ansary et al., 2001; Al-Ani et al., 1998; Cadmus et al., 2006; Refai, 2000). It is believed that this disease is more common in males as compared to females (Hussein et al., 2005) however, there are some reports claiming that the prevalence of this disease is independent of animal's sex (Muma et al., 2006). It mainly affects the mature cows as Amin et al. (2005) reported that animals having age above 4 years are more prone to this infection.

In dogs the primarily signs of brucellosis are abortion, scrotal inflammation and orchitis. Contact with aborted fetus transmits disease from one to another, which results in damage to genitals and lymphatic system. This disease can be studied by various serological and bacteriological techniques, among those Tube Agglutination Test (TAT) is more common (Pickerill and Carmichael, 1972). A study was conducted by Flores-Castro et al. (1977) to determine canine brucellosis of naturally infected dogs in Mexico city. They diagnosed the disease using both serological and bacteriological methods and found a very high rate of Brucella canis infection in stray dogs $(11.8 \%)$ of Mexico city. DNA based detection techniques are very successful in its diagnosis; in a study researchers from Italy used whole blood and buffy coat of infected animals to successfully detect the pathogenic organism through real-time PCR (Corrente et al., 2010). They reported the detection of a brucellosis positive case through real-time PCR, which was previously not detectable through standard cultural practices. In another study, Keid et al. (2010) compared the sensitivity of PCR by using two different samples in 72 dogs. They compared both serum and blood PCR assays' sensitivity and concluded that blood PCR assay is more sensitive in detecting brucellosis infected dogs. Detection of brucellosis by PCR is not only applicable in dogs as Gupta et al. (2010) confirmed the results of their newly developed ELISA assay (for brucellosis detection) by using antibody gene specific PCR primers in goats.

Colibacillosis: It is a bacterial disease of animals that can also infect humans but it is more common in poultry birds (Rahman et al., 2004). A review study by Kabir (2010) showed that avian colibacillosis is a major disease of chicken and its presence throughout the world could be the limiting factor for proliferation of chicken industry. Roy et al. (2009) found that $31.81 \%$ of calves were infected with colibacillosis and $E$. coli was present in all infected animals. In another study conducted in Spain on red-legged partridges (used for hunting), high prevalence rate of $E$. coli was reported (Diaz-Sanchez et al., 2012). Prevalence of pathogen was higher in farm reared redlegged partridges (45\%) as compared to wild and restocked red-legged partridges. It shows that persons working on farm are at high risk of developing this disease.

Dogs are susceptible to this disease especially in early days of puppies feeding. Infected genetial tract is also a source of infection, which results in abortion or septicaemic (blood poisoning) death of puppies (Bjurstrom, 1993; Linde, 1983). In dogs the most common symptoms of this disease are dehydration, lack of appetite, increased heart rate, cold skin, watery diarrhea and secretion of bluish mucus membranes. A case of 90 days old puppy was observed, which died due to chronic diarrhea (Wada et al., 1996). Further investigations showed the presence of $E$. coli attached with the stomach wall of infected puppy. Studies on $E$. coli (causative agent of colibacillosis) diagnosis by PCR have been reported in different organisms (Mora et al., 2009; Seidavi et al., 2010) but studies on PCR assay development to detect colibacillosis in dogs are scarce.

Giardiasis: It is a zoonotic disease more commonly reported in developing countries, especially in areas 
where sanitation practices are very poor (Oberhuber et al., 1997). Giardia lamblia is very common protozoan parasite of animals; a worldwide study was conducted to determine its prevalence (Feng and Xiao, 2011) and Uganda was found to be the place where its infection rate was highest among humans (40.7\%). Julio et al. (2012) studied the Giardia infection rate among humans and found that its infection rate is higher in children of $0-5$ years age, no difference in its prevalence was found between male and females. It was more prevalent in those who have contact with dogs and poor drainage system at homes. Varying infection rate has been reported in cattle $(3.7-57.8 \%)$, sheep $(1.5-55.6 \%)$, goats $(12.3-42.2 \%), \operatorname{dogs}(2-64.3 \%)$ and cats (2-44.4\%) (Fayer et al., 2006; Overgaauw et al., 2009; Palmer et al., 2008; O'Handly et al., 2000; Ruiz et al., 2008; Johnston et al., 2010; Hsu et al., 2007; Giangaspero et al., 2005). The major source of its spread is through water bodies, contaminated with feces of infected animals (Marshall et al., 1997). This disease transmits through ingesting infectious cysts from feces of infected animals and can be diagnosed by analyzing the fecal smear. Symptoms are acute, non-continuos or chronic in nature and in some cases soft, frothy and greasy diarrhea with a strong awful odor or mucus is reported.

In a study Paz-e-Silva et al. (2012) collected 300 fecal samples of dogs in Brazil; they analyzed these samples for detection of Giardia duodenalis through PCR. Small subunit ribosomal DNA (SSU-rDNA) and Glutamate Dehydrogenase $(G D H)$ genes were targeted for PCR analysis and genetically characterized the G. duodenalis by Restriction Fragment Length Polymorphism (RFLP) and sequencing of GDH gene. Traub et al. (2009) conducted a study in Bangkok to analyze the prevalence of $G$. duodenalis in human and canine populations. They used SSU-rDNA gene for PCR detection and concluded that the PCR is the most reliable test for detection of G. duodenalis.

Lyme: Lyme is a bacterium disease mainly caused by Borrelia burgdorferi, a group of spirochete bacterial species transmitted by slow-feeding and hard-shelled deer ticks. It is a zoonotic disease discovered in Lyme town of USA in 1975. A study was conducted by Milewski et al. (2011) in USA to evaluate the Lyme arthritis in children, $31 \%$ children were found to be infected. Zhang et al. (2010) studied the prevalence of Borrelia burgdorferi sensu lato (causative agent of lyme) in rodents. They reported $22.86 \%$ infection rate in 7 species of rodents, these rodents serve as the source of this pathogen in environment. Seabirds may be the source of spreading
Lyme disease in environment and to check this hypothesis Duneau et al. (2008) studied a case of seabirds and found that $26 \%$ of seabirds were infected with Lyme borreliosis.

In dogs common symptoms of Lyme disease are difficulty in breathing, joint inflammation and difficulty in walking with arched back (Wasmoen et al., 1992). Studying background history and blood testing of dog plays important role in diagnosis of this disease. Appel et al. (1993) used ELISA technique for its diagnosis and found high level of antibodies in infected dogs after 4-6 weeks of infection. In a case study Levy and Magnarelli, 1992) reported that only 5\% of infected dogs showed physical signs of Lyme disease; it indicates that detection of this disease depending solely on its physical symptoms is not reliable.

Lyme disease is thought to be causing the neurological disorders and to confirm this Krimer et al. (2011) conduct a study on dogs that were experimentally challenged with $B$. burgdorferi-infected ticks. No DNA was found in tissues of dogs that were infected ticks carrying B. burgdorferi. Many other studies also reported poor detection of this disease by using PCR (Chou et al., 2006; Hutton et al., 2008; Leschnik et al., 2010), on the other hand analysis of infected animals' seroreactivity for its diagnosis could serve the purpose very well (Kiss et al., 2011; Mircean et al., 2012). PCR could be useful to identify dogs that are at risk to this pathogen (B. burgdorferi) by isolating ticks from their bodies and then screening them through PCR, targeting the B. burgdorferi DNA (Smith et al., 2012).

Leptospirosis: It is a bacterial infection caused by Leptospira interrogans, penetrating through skin and then spread throughout the body (Andre et al., 1994). It occurs mostly under wet environmental conditions as these bacteria are more persistent in marshy or muddy areas. Contaminated water, mud and urine obtained from infected animals act as the source of infection. Jansen et al. (2007) studied the infection rate of leptospirosis in wild boars (18\%) and found that wild boars are important source to cause infection in humans. Zhang et al. (2012) determined the spread of this zoonotic disease among humans during last two decades in China; its infection rate was high due to heavy rains and floods, out of total infected cases $60 \%$ humans were infected due to Leptospira interrogans serogroup Icterohaemorrhagiae serovar Lai. Prevalence of leptospirosis in patients suspected to be infected with dengue virus was observed by Sergio et al. (2012), they reported 48, 6 and $12 \%$ of suspected patients were infected with dengue, leptospirosis and both dengue and leptospirosis pathogens, respectively. About $34 \%$ of these suspected 


\section{J. Anim. Vet. Adv., 11 (11): 1954-1964, 2012}

individuals were negative to both infections. Prevalence of leptospirosis was high in patients suffering with dengue fever.

In dogs most commonly observed signs are sudden illness, restriction in muscle movement, shivering, weakness, lack of appetite, vomiting, spontaneous cough, yellow skin and diarrhea. Blood and urine analysis with whole history of symptoms are required for its better diagnoses. Due to zoonotic nature of this disease it should be handle very carefully (McDonough, 2001). Microscopic Agglutination Test (MAT) is the commonly used diagnostic method for leptospirosis detection. Miller et al. (2011) conducted a study in, which they compared the MAT results of same samples obtained from different laboratories. They concluded that though this test is good in diagnosing this disease but it is not valid in predicting the infecting seriogroup. In addition to this, detection of pathogen at early stage of disease is not possible with MAT. Pathogens that cause Leptospirosis mostly colonize renal tubules of infected animals so analyzing the urine samples of infected animals could be helpful in detection of this disease. Rojas et al. (2010) designed a Real-Time PCR assay targeting the lipL32 gene sequence, which is highly conserved among pathogenic leptospires. They analyzed 525 urine samples of dogs through real-time PCR and concluded that this disease was $7.05 \%$ prevalent among individuals of tested population. Detection of pathogen through real-time PCR is very fast as compared to antibody based diagnostic techniques (Slack et al., 2007; Ahmed et al., 2009).

Salmonellosis: It is an infection caused by Salmonella and host of this bacterium may carry more than one species of this bacterium, which serves as a source of its transmission. Readel et al. (2010) conducted a study to observe turtles as carrier and source of salmonellosis infection, Salmonella was found in $11 \%$ of total population under study, it clearly shows the high prevalence rate of this pathogen in turtles. Prevalence of Salmonella in shedding of cattle herds was observed (Cummings et al., 2010) and 77\% of herds indicated the prevalence of Salmonella. A survey for Salmonella prevalence was carried out at a pig farm in Spain by Vico et al. (2011) and they found Salmonella was present in $94 \%$ of studied herds; moreover, $31 \%$ of studied individuals were infected with this pathogen. These animals can be the source of disease transmission in humans, Guo et al. (2011) estimated the relative contribution of food products to cause infection in humans by using a model developed by them. They estimated the relative contribution of chicken $(48 \%)$ ground beef ( $28 \%$ ) turkey (17\%) and egg (6\%) products in causing infection to humans.
Young and old $\operatorname{dog} s$ are more susceptible to it because of low immunity levels. Among its symptoms fever, diarrhea, vomiting, anorexia, weight loss, dehydration, vaginal discharges and swollen lymph nodes are most common. It is difficult to diagnose because its symptoms overlap with symptoms of other diseases, so urine and feces samples are analyzed in laboratory for its diagnosis. Finley et al. (2007) conducted an experiment in, which they fed Salmonella contaminated diet to 12 dogs. They found Salmonella in feces of seven dogs and concluded that under natural conditions feces of infected dogs could serve as source for spread of this disease. Moreover they didn't find any clinical signs of infection in infected dogs.

Commonly used methods for the detection of pathogen causing salmonellosis are selective culture methods, biochemical identification and serotyping; all these methods are time consuming and laborious in nature. Real-time PCR is fast and specific for pathogen detection, hence it could play a useful role to overcome the demerits of conventionally used diagnostic methods for detection of this pathogen (Marks et al., 2003). In another study Schuurman et al. (2007) conducted a research and compared different diagnostic methods with real-time PCR to detect Salmonella enterica. They concluded that by employing real-time $\mathrm{PCR}$, on an average 2.9-3.8 days can be saved as compared to conventional diagnostic methods.

Campylobacteriosis: It is a bacterial infection caused by Campylobacter jejuni or C. coli, which lives in gut (gastrointestinal tract) of healthy mammals and food serves as a source of its infection in humans. A study was conducted to observe the prevalence of Campylobacter in different food items in Pakistan (Hussain et al., 2007), overall prevalence of Campylobacter was $21.5 \%$ out of, which prevalence rate of $C$. jejuni and $C$. coli was 70.6 and $29.6 \%$, respectively. In addition, they reported the varying prevalence rate of this pathogen in different food items like chicken (48\%), beef $(10.9 \%)$, mutton $(5.1 \%)$, vegetable salad $(40.9 \%)$, sandwiches $(32 \%)$, cheese $(11 \%)$ and milk $(10.2 \%)$. Another study was conducted to determine the prevalence of Campylobacter sp. (Strachana et al., 2012) in liver of different animals obtained from retail market; pathogen was detected in 81 , 69,79 and $78 \%$ of chicken, cattle, pig and sheep samples, respectively. Moreover, it was found that strain of pathogen isolated from chicken liver was similar to human infecting strain. Madoroba et al. (2011) studied the prevalence of Campylobacter among Southern African cattle and reported $1.9 \%$ prevalence of C. foetus, which is a causative agent of infertility and abortion in these animals. 
It is more common disease in puppies with age of $<6$ six months; it can be transmitted to non-infected animals through contaminated feces and food. The most common signs are vomiting, anorexia, fever and enlarged lymph nodes. A study was conducted to observe the transmission of Campylobacter jejuni or C. coli in dogs, chicken and humans (Workman et al., 2005). Campylobacter jejuni was also detected in humans $(63.6 \%)$, chickens $(86.6 \%)$, dogs $(51.5 \%)$ and chicken meat (79.8\%); in addition to this chicken meat was found to be the main source of its transmission to humans.

Detection of this pathogen by using DNA based diagnostic techniques has been reported by many researchers, Chaban et al. (2009) developed a real-time PCR assay using cpn60 gene specific primers for detection of different Campylobacter species. After optimization of real-time PCR assay they analyzed fecal samples of dogs obtained from dogs and concluded that this newly developed assay will facilitate the investigators to study Campylobacter species without employing any bacterial culture technique. Many other researchers have used real-time PCR assay to detect Campylobacter species by using cpn60 gene specific primers (Chaban et al., 2010, 2012).

Urinary tract infections: Some bacteria may enter and colonize in bladder or upper portion of urethra resulting in infection, which is commonly known as Urinary Tract Infection (UTI). Kolawole et al. (2009) studied the prevalence of UTI among patients, examined at Dalhatu Araf Specialist Hospital, Lafia, Nasarawa State, Nigeria, $60 \%$ of patients were infected. Another case of ill children was studied by O'Brien et al. (2011), they reported 4\% urinary tract infection among studied children population. In another study, Shaikh et al. (2008) found that prevalence of UTI was $7 \%$ in studied population of children. The persons with weak immune system due to any other disease are at high risk of developing this disease.

Dogs of all age are at risk of this infection but older and female dogs are more susceptible to these infections. E. coli, Staphylococcus and Proteus sp. are the commonly found causative agents of this infection. The most commonly observed signs are difficulty in urinating, blood in urine and continuos urination in small amounts. Urine analysis is more valuable for its diagnosis; presence of pus and blood are among the initial signs of infection. To identify pathogen responsible for UTI, 385 samples obtained from dogs showing disease symptoms were analyzed (Wooley and Blue, 1976). Researchers identified three bacterial types; Escherichia coli, Proteus sp. and Staphylococcus aureus among all tested samples. Olby et al. (2010) reported that chances of developing UTI are high in dogs with acute intervertebral disc extrusion. Available data on diagnosis of UTI in dogs is not enough to develop a PCR assay with reproducible results. But the common genetic background of pathogenic $E$. coli strains of animals and humans (Clermont et al., 2011) could be used to develop new PCR assays on the basis of previous reports on detection of $E$. coli in different organisms.

\section{CONCLUSION}

Early detection of infection is essential to ensure effective control of disease as the time of infection increases so do the microbial load in body; infection can be controlled easily when pathogens are less in number. Moreover, chances of resistance development against used antimicrobial increases with the number of pathogens. The need of early infection control becomes more intense when we deal with pathogens that are of zoonotic nature to ensure the health of both humans and animals. Dog is one of the most common domestic animals and often develops a close physical relationship with humans. Hence, current review was conducted to through some light on prevalence and diagnosis of dog bacterial diseases that are also transmittable to humans. PCR was found to be effective in detection of pathogen causing brucellosis, giardiasis, leptospirosis, salmonellosis and campylobacteriosis but when dealing with Lyme, PCR doesn't seem to be much effective. In case of colibacillosis and UTI sufficient data was not available for detection of these diseases through PCR, which emphasizes the need of future research on developing PCR assays for detection of these diseases at their early stage of development. Knowledge about conserved genomic regions and genes that are important for virulence of these pathogens will be helpful to develop organism independent PCR assays. Many other DNA based diagnostic techniques (e.g., RFLP) can be combined with PCR to increase the accuracy of pathogen detection. For example $E$. coli is a commonly found organism in microflora of both humans and animals, some of its strains are pathogenic in nature so combination of PCR with other DNA based diagnostic techniques could be used for precise detection of pathogenic bacterial strains. In nutshell PCR is a good technique for early detection of pathogenic bacteria but still further research is required to cover all bacterial diseases. 


\section{REFERENCES}

APPA, 2011. APPA national pet owners survey 20112012. American Pet Products Association, http://www.americanpetproducts.org/pubs_survey. asp.

Abd El-Razik, K.A., H.M. Desoukey and W.M. Ahmed, 2007. Investigations on brucellosis in Egyptian baladi does with emphasis on evaluation of diagnostic techniques. Pak. J. Biol. Sci., 10: 342-348.

Ahmed, A., M.F.M. Engelberts, K.R. Boer, N. Ahmed and R.A. Hartskeerl, 2009. Development and validation of a real-time PCR for detection of pathogenic Leptospira species in clinical materials. PLoS ONE, Vol. 4, 10.1371/journal.pone.0007093.

Ahmed, M.O., N.J. Williams, P.D. Clegg, J.C. van Velkinburgh, K.E. Baptiste and M. Bennett, 2012. Analysis of risk factors associated with antibioticresistant Escherichia coli. Microb. Drug Resistance, 18: 161-168.

Ahmed, R. and M. A. Munir, 1995. Epidemiological investigations of brucellosis in Pakistan. Pak. Vet. J., 15: $169-172$.

Ahmida, M., 2011. Antidiabetic, antihyperlipedemic and antioxidant effects of aqueous extract of the roots of Cynara cornigera in alloxan-induced experimental diabetes mellitus. Int. J. Pharmacol., 7: 782-789.

Akhtar, M. and N. Latif, 2000. Antibiotic therapy of brucella infected patients at allied and district headquarter hospitals, Faisalabad. Pak. J. Biol. Sci., 3: 363-364.

Al-Ani, F.K., M. Al-Sharrifi andF. Khalil, 1998. Serological survey on camel brucellosis in Iraq. Camel Newslett., 14: 32-33.

Amin, K.M., M.B. Rahman, M.S. Rahman, J.C. Han, J.H. Park and J.S. Chae, 2005. Prevalence of brucella antibodies in sera of cows in Bangladesh. J. Vet. Sci., 6: 223-226.

Anam, K., A.G. Suganda, E.Y. Sukandar and L.B.S. Kardono, 2010. Antibacterial effect of component of Terminalia muelleri Benth. against Staphylococcus aureus. Int. J. Pharmacol., 6: 407-412.

Andre, F.G., C.N. Ruvoen and J. P. Ganiere, 1994. Dog leptospirosis: New topics. Recueil Med. Vet., 170: 663-668.

Appel, M.J., S. Allan, R.H. Jacobson, T.L. Lauderdale and Y.F. Chang et al., 1993. Experimental lyme disease in dogs produces arthritis and persistent infection. J. Infect. Dis., 167: 651-664.

Bjurstrom, L., 1993. Aerobic bacteria occurring in the vagina of bitches with reproductive disorders. Acta Vet. Scand., 34: 29-34.
Cadmus, S.I.B., I.F. Ijagbone, H.E. Oputa, H.K. Adesokan and J.K. Stack, 2006. Serological survey of brucellosis in livestock animals and workers in Ibadan, Nigeria. Afr. J. Biomed. Res., 9: 163-168.

Capasso, L., 2002. Bacteria in two-millennia-old cheese and related epizoonoses in roman populations. J. Infect., 45: 122-127.

Chaban, B., K.M. Musil, C.G. Himsworth and J.E. Hill, 2009. Development of cpn60-based real-time quantitative PCR assays for the detection of 14 Campylobacter species and application to screening of canine fecal samples. Applied Environ. Microbiol., 75: 3055-3061.

Chaban, B., M. Ngeleka and J.E. Hill, 2010. Detection and quantification of 14 Campylobacter species in pet dogs reveals an increase in species richness in feces of diarrheic animals. BMC Microbiol., Vol. 10, 10.1186/1471-2180-10-73.

Chaban, B., M.G. Links and J.E. Hill, 2012. A molecular enrichment strategy based on cpn60 for detection of Epsilon-Proteobacteria in the dog fecal microbiome. Microbial Ecol., 63: 348-357.

Chou, J., A. Wunschmann, E. Hodzic and D.L. Borjesson, 2006. Detection of Borrelia burgdorferi DNA in tissues from dogs with presumptive Lyme borreliosis. J. Am. Vet. Med. Associat., 229: $1260-1265$.

Clermont, O., M. Olier, C. Hoede, L. Diancourt and S. Brisse et al., 2011. Animal and human pathogenic Escherichia coli strains share common genetic backgrounds. Infect. Genet. Evol., 11: 654-662.

Corrente, M., D. Franchini, N. Decaro, G. Greco and M. D'Abramo et al., 2010. Detection of Brucella canis in a dog in Italy. New Microbiol., 33: 337-341.

Cummings, K.J., L.D. Warnick, M. Elton, Y.T. Grohn, P.L. McDonough and J.D. Siler, 2010. The effect of clinical outbreaks of Salmonellosis on the prevalence of fecal Salmonella Shedding among dairy cattle in New York. Food Borne Pathogens Dis., 7: 815-823.

Diaz-Sanchez, S., A.M. Moriones, F. Casas and U. Hofle, 2012. Prevalence of Escherichia coli, Salmonella sp. and Campylobacter sp. in the intestinal flora of farmreared, restocked and wild red-legged partridges (Alectoris rufa): Is restocking using farm-reared birds a risk? Eur. J. Wild. Res., 58: 99-105.

Duneau, D., T. Boulinier, E. Gomez-Diaz, A. Petersen, T. Tveraa, R.T. Barrett and K.D. McCoy, 2008. Prevalence and diversity of Lyme borreliosis bacteria in marine birds. Genet. Evolut., 8: 352-359.

El-Ansary, E.H.H., B.A. Mohammed, A.R.A. Hamad and A.G.O. Karom, 2001. Brucellosis among animals and human contacts in eastern Sudan. Saudi Med. J., 22: $577-579$. 
Farooq, K., A. Hameed, T. Javed, I. Ullah, A.W. Khan and H. Khan, 2006. Comparative immunological response of commercial oil based and liposomal vaccines of avian influenza H7. Pak. J. Biol. Sci., 9: 2402-2410.

Fayer, R., M. Santin, J.M. Trout and J.P. Dubey, 2006. Detection of Cryptosporidium felis and Giardia duodenalis assemblage $\mathrm{F}$ in a cat colony. Vet. Parasitol., 140: 44-53.

Feng, Y. and L. Xiao, 2011. Zoonotic potential and molecular epidemiology of Giardia Species and Giardiasis. Clin. Microbiol. Rev., 24: 110-140.

Finley, R., C. Ribble, J. Aramini, M. Vandermeer, M. Popa, M. Litman and R. Reid-Smith, 2007. The risk of Salmonellae shedding by dogs fed Salmonellacontaminated commercial raw food diets. Can. Vet. J., 48: $69-75$.

Flores-Castro, R., F. Suarez, C. Ramirez-Pfeiffer and I.E. Carmichael, 1977. Canine Brucellosis: Bacteriological and serological investigation of naturally infected dogs in Mexico city. J. Clinic. Micro., 6: 591-597.

Geidam, Y.A., A.G. Ambali and P.A. Onyeyili, 2007. Phytochemical screening and antibacterial properties of organic solvent fractions of Psidium guajava aqueous leaf extracts. Int. J. Pharmacol., 3: 68-73.

Gholami, S., A. Daryani, M. Sharif, A. Amouei and I. Mobedi, 2011. Seroepidemiological survey of helminthic parasites of stray dogs in sari city, Northern Iran. Pak. J. Biol. Sci., 14: 133-137.

Giangaspero, A., B. Paoletti, R. Iorio and D. Traversa, 2005. Prevalence and molecular characterization of Giardia duodenalis from sheep in central Italy. Parasitol. Res., 96: 32-37.

Guo, C., R.M. Hoekstra, C.M. Schroeder, S.M. Pires and K.L. Ong et al., 2011. Application of bayesian techniques to model the burden of human salmonellosis attributable to U.S. food commodities at the point of processing: Adaptation of a danish model. Foodborne Pathogens Dis., 8: 509-516.

Gupta, V.K., R. Kumari, J. Vohra, S.V. Singh and V.S. Vihan, 2010. Comparative evaluation of recombinant BP26 protein for serological diagnosis of Brucella melitensis infection in goats. Small Rumin. Res., 93: 119-125.

Hadipour, M.M., 2011. Seroprevalence of H9N2 avian influenza virus in human population in boushehr province, Iran. Asian J. Anim. Vet. Adv., 6: 196-200.

Hadizadeh, I., B. Peivastegan and M. Kolahi, 2009. Antifungal activity of nettle (Urtica dioica L.), colocynth (Citrullus colocynthis L. schrad), oleander (Nerium oleander L.) and konar (Ziziphus spinachristi L.) extracts on plants pathogenic fungi. Pak. J. Biol. Sci., 12: 58-63.
Haque, M., M.O. Ullah and K. Nahar, 2009. In vitro Antibacterial and Cytotoxic Activities of Different Parts of Plant Swietenia mahagony. Pak. J. Biol. Sci., 12: 599-602.

Harun-Or-Rashid, M., N. Karim, M.A. Gafur, M. Golam Sadik, A.S.M. Anisuzzaman, N. Sugimoto and A.T.M. Zafrul Azam, 2006. Isolation and biological activities of chemical constituents from the stems of Ipomoea turpethum. Pak. J. Biol. Sci., 9: 2261-2266.

Hassan, S.W., R.A. Umar, M.J. Ladan, P. Nyemike, R.S.U. Wasagu, M. Lawal and A.A. Ebbo, 2007. Nutritive value, phytochemical and antifungal properties of Pergularia tomentosa L. (Asclepiadaceae). Int. J. Pharmacol., 3: 334-340.

Hedayatizadeh-Omran, A., A. Rafiei, M. Hajilooi and M. Haghshenas, 2010. Interferon-gamma low producer genotype +5644 over presented in patients with focal brucellosis. Pak. J. Biol. Sci., 13: 1036-1041.

Hsu, B.M., H.Y. Wun and P.C. Hsu, 2007. Prevalence and genotyping of Giardia in husbandry systems in Taiwan. Parasitol. Res., 101: 275-280.

Hussain, I., M.S. Mahmood, M. Akhtar and A. Khan, 2007. Prevalence of Campylobacter species in meat, milk and other food commodities in Pakistan. Food Microbiol., 24: 219-222.

Hussein, A.A., A.S. Sayed and M.A. El-Feki, 2005. Seroepidemiological study on human brucellosis in Assiut Governorate. Egypt. J. Immumol., 12: 49-56.

Hutton, T.A., R.E. Goldstein, B.L. Njaa, D.Z. Atwater, Y.F. Chang and K.W. Simpson, 2008. Search for Borrelia burgdorferi in kidneys of dogs with suspected "Lyme nephritis". J. Vet. Int. Med., 22: 860-865.

Icen, H., S. Sekin, A. Simsek, A. Kochan, O.Y. Celik and M.G. Altas, 2011. Prevalence of Dirofilaria immitis, Ehrlichia canis, Borrelia burgdorferi infection in dogs from diyarbakir in Turkey. Asian J. Anim. Vet. Adv., 6: 371-378.

Iweala, E.E.J., I.C. Obichi and O.E. Omotosho, 2011. Biochemical and histological responses of hepatotoxic rats fed Musa paradisiaca L. supplemented diet. Int. J. Pharmacol., 7: 471-477.

Jansen, A., E. Luge, B. Guerra, P. Wittschen and A.D. Gruber et al., 2007. Leptospirosis in urban wild boars, Berlin, Germany. Emerg. Infect. Dis., 13: 739-742.

Jazani, N.H., M. Zartoshti and S. Shahabi, 2008. Antibacterial effects of iranian Cuminum cyminum essential oil on burn isolates of Pseudomonas aeruginosa. Int. J. Pharmacol., 4: 157-159.

Johnston, A.R., T.R. Gillespie, I.B. Rwego, T.L. McLachlan, A.D. Kent and T.L. Goldberg, 2010. Molecular epidemiology of cross-species Giardia duodenalis transmission in western Uganda. PLoS Negl. Trop. Dis., 4: e683-e683. 
Joseph, B., S.N. Sheeba, S. Sujatha and K. Thanalakshmi, 2011. Study of antibiogram and drug resistance for some bacterial infection from the human internal fluid (CSF, ascitic fluid and synovial fluid). Int. J. Pharmacol., 7: 463-470.

Julio, C., A. Vilares, M. Oleastro, I. Ferreira and S. Gomes et al., 2012. Prevalence and risk factors for Giardia duodenalis infection among children: A case study in Portugal. Parasit. Vectors, 5: 22-22.

Junaidu, A.U., M.D. Salihu and M.L. Gulumbe, 2006. Seroprevalence of brucellosis in sheep in Sokoto city abattoir. Pak. J. Biol. Sci., 9: 2696-2698.

Kabir, S.M.L., 2010. Avian colibacillosis and salmonellosis: A closer look at epidemiology, pathogenesis, diagnosis, control and public health concerns. Int. J. Environ. Res. Public Health, 7: 89-114.

Karami, A., P. Hindeersson, N. Hoiby, S. Morovvati and A. Khalilpour, 2006. Linear and circular plasmids in skin and cerebrospinal fluid isolates of Borrelia burgdorferi agent of lyme disease. Pak. J. Biol. Sci., 9: 2787-2793.

Karim, A. and U. Kanwal, 2011. Parquetina nigrescens checks the ulceration and oxidation. Int. J. Pharmacol., 7: 797-798.

Karim, A., M.N. Sohail, S. Munir and S. Sattar, 2011. Pharmacology and phytochemistry of Pakistani herbs and herbal drugs used for treatement of diabetes. Int. J. Pharmacol., 7: 419-439.

Karou, S.D., D.P. Ilboudo, W.M.C. Nadembega, Y. Ameyapoh and D. Ouermi et al., 2009. Antibiotic resistance in urinary tract bacteria in ouagadougou. Pak. J. Biol. Sci., 12: 712-716.

Karthishwaran, K. and S. Mirunalini, 2010. Therapeutic potential of Pergularia daemia (Forsk.): The ayurvedic wonder. Int. J. Pharmacol., 6: 836-843.

Keid, L.B., R.M. Soares, S.A. Vasconcellos, V.R. Salgado, J. Megid and L.J. Richtzenhain, 2010. Comparison of a PCR assay in whole blood and serum specimens for canine brucellosis diagnosis. Vet. Rec., 167: 96-99.

Kiss, T., D. Cadar, A.F. Krupaci, A. Bordeanu and G.F. Brudasca et al., 2011. Serological reactivity to borrelia burgdorferi sensu lato in dogs and horses from distinct areas in Romania. Vector Borne Zoonotic Dis., 11: 1259-1262.

Kolawole, A.S., O.M. Kolawole, Y.T. Kandaki-Olukemi, S.K. Babatunde, K.A. Durowade and C.F. Kolawole, 2009. Prevalence of Urinary Tract Infections (UTI) among patients attending Dalhatu Araf Specialist Hospital, Lafia, Nasarawa State, Nigeria. Int. J. Med. Med. Sci., 1: 163-167.
Krimer, P.M., A.D. Miller, Q. Li, D.A. Grosenbaugh, L. Susta and S.J. Schatzberg, 2011. Molecular and pathological investigations of the central nervous system in Borrelia burgdorferi-infected dogs. J. Vet. Diagn. Invest., 23: 757-763.

Leonard, E.K., D.L. Pearl, R.L. Finley, N. Janecko, R.J. Reid-Smith, A.S. Peregrine and J.S. Weese, 2012. Comparison of antimicrobial resistance patterns of Salmonella spp. and Escherichia coli recovered from pet dogs from volunteer households in Ontario (2005-06). J. Antimicrob. Chemother., 67: 174-181.

Leschnik, M.W., G. Kirtz, G. Khanakah, G. Duscher, E. Leidinger, J.G. Thalhammer, A. Joachim and G. Stanek, 2010. Humoral immune response in dogs naturally infected with Borrelia burgdorferi sensu lato and in dogs after immunization with a Borrelia vaccine. Clin. Vaccine Immunol., 17: 828-835.

Levy, S.A. and L.A. Magnarelli, 1992. Relationship between development of antibodies to Borrelia burgdorferi in $\operatorname{dogs}$ and the subsequent development of $1 \mathrm{imb} /$ joint borreliosis. JAVMA, 200: 344-347.

Linde, C., 1983. Partial abortion associated with genital Escherichia coli infection in a bitch. Vet. Rec., 112: 454-455.

Madoroba, E., A. Gelaw, T. Hlokwe and M. Mnisi, 2011. Prevalence of Campylobacter foetus and Trichomonas foetus among cattle from Southern Africa. Afr. J. Biotechnol., 10: 10311-10314.

Majidzadeh, K., V. Karimi, M. Soleimanidor, A.S. Estabragh, A. Barin and A.G. Langeroudi, 2011. Phylogenetic study on Nonstructural (NS) gene of H9N2 isolated from Broilers in Iran during 1998-2007. Pak J. Biol. Sci., 14: 838-843.

Malabadi, R.B. and S.V. Kumar, 2007. Assessment of antifungal activity of some medicinal plants. Int. J. Pharmacol., 3: 499-504.

Manikandan, S., S. Ganesapandian, M. Singh, N. Sangeetha and A.K. Kumaraguru, 2011. Antimicrobial activity of seaweeds against multi drug resistant strains. Int. J. Pharmacol., 7: 522-526.

Marks, S.L., S.C. Rankin, B.A. Byrne and J.S. Weese, 2003. Enteropathogenic bacteria in dogs and cats: Diagnosis, epidemiology, treatment and control. J. Vet. Internal Med., 25: 1195-1208.

Marshall, M.M., D. Naumovitz, Y. Ortega and C.R. Sterling, 1997. Waterborne protozoan pathogens. Clin. Microbiol. Rev., 10: 67-85.

McDonough, P.L., 2001. Leptospirosis in dogs-current status. International Veterinary Information Service, Ithaca, NY., USA. http://www.ivis.org/advances/ infect_dis_carmichael/mcdonough/ivis.pdf. 
Mehrabian, S. and E. Jaberi, 2007. Isolasion, identification and antimicrobial resistance patterns of salmonella from meat products in Tehran. Pak. J. Biol. Sci., 10: $122-126$.

Melek, I.M., T. Duman and E. Turali, 2005. Bilateral isolated facial paralysis due to Lyme disease. J. Biological Sci., 5: 532-535.

Memish, Z., 2001. Brucellosis control in Saudi Arabia: Prospects and challenges. J. Chemother Suppl., 1: 11-17.

Milewski, M.D., A.I. Cruz, C.P. Miller, A.T. Peterson and B.G. Smith, 2011. Lyme arthritis in children presenting with joint effusions. J. Bone Joint Surg., 93: 252-260.

Miller, M.D., K.M. Annis, M.R. Lappin and K.F. Lunn, 2011. Variability in results of the microscopic agglutination test in dogs with clinical leptospirosis and dogs vaccinated against leptospirosis. J. Vet. Internal Med., 25: 426-432.

Mircean, V., M.O. Dumitrache, A. Gyorke, N. Pantchev, R. Jodies, A.D. Mihalca and V. Cozma, 2012. Seroprevalence and geographic distribution of dirofilaria immitis and tick-borne infections (Anaplasma phagocytophilum, Borrelia burgdorferi sensu lato and Ehrlichia canis) in dogs from Romania. Vector-Borne Zoonotic Dis., (In Press). 10.1089/vbz.2011.0915.

Momtaz, S. and M. Abdollahi, 2010. An update on pharmacology of Satureja species: From antioxidant, antimicrobial, antidiabetes and anti-hyperlipidemic to reproductive stimulation. Int. J. Pharmacol., 6: 346-353.

Moniri, R. and K. Dastehgoli, 2007. Antimicrobial resistance among Escherichia coli strains isolated from healthy and septicemic chickens. Pak. J. Biol. Sci., 10: 2984-2987.

Moore, J.A., 1969. Brucella canis infection in dogs. J. Am. Vet. Med. Assoc., 155: 2034-2037.

Mora, A., C. Lopez, G. Dabhi, M. Blanco and J.E. Blanco et al., 2009. Extraintestinal pathogenic Escherichia coli $\mathrm{O} 1: \mathrm{K} 1: \mathrm{H} 7 / \mathrm{NM}$ from human and avian origin: Detection of clonal groups B2 ST95 and D ST59 with different host distribution. BMC Microbiol., Vol. 9 10.1186/1471-2180-9-132.

Motamedi, H., E. Darabpour, M. Gholipour and S.M.S. Nejad, 2010. Antibacterial effect of ethanolic and methanolic extracts of Plantago ovata and Oliveria decumbens endemic in iran against some pathogenic bacteria. Int. J. Pharmacol., 6: 117-122.

Muma, J.B., K.L. Samui, V.M. Siamudaala, J. Oloya and G. Matope et al., 2006. Prevalence of antibodies to Brucella spp. and individual risk factors of infection in traditional cattle, goats and sheep reared in livestock-wildlife interface areas of Zambia. Trop. Anim. Health Prod., 38: 195-206.
O'Handly, R.M., M.E. Olson, D. Fraser, P. Adams and R.C. Thompson, 2000. Prevalence and genotype characterisation of Giardia in dairy calves from Western Australia and Western Canada. Vet. Parasitol., 90: 193-200.

Oberhuber, G., N. Kastner and M. Stolte, 1997. Giardiasis: A histologic analysis of 567 cases. Scand. J. Gastroenrol., 32: 48-51.

Olby, N.J., E. MacKillop, S. Cerda-Gonzalez, S. Moore and K.R. Munana et al., 2010. Prevalence of urinary tract infection in dogs after surgery for thoracolumbar intervertebral disc extrusion. J. Vet. Intern. Med., 24: 1106-1111.

Overgaauw, P.A.M., L. van Zutphen, D. Hoek, F.O. Yaya and J. Roelfsema et al., 2009. Zoonotic parasites in fecal samples and fur from dogs and cats in the Netherlands. Vet. Parasitol., 163: 115-122.

Oyedemi, S.O., G. Bradley and A.J. Afolayan, 2011. Beneficial effect of aqueous stem bark extracts of Strychnos Henningsii gilg in streptozotocinnicotinamide induced type 2 diabetic wistar rats. Int. J. Pharmacol., 7: 773-781.

O'Brien, K., N. Stanton, A. Edwards, K. Hood and C.C. Butler, 2011. Prevalence of urinary tract infection (UTI) in sequential acutely unwell children presenting in primary care: Exploratory study. Scand. J. Prim. Health Care, 29: 19-22.

Palmer, C.S., R.J. Traub, I.D. Robertson, G. Devlin, R. Rees and R.C.A. Thompson, 2008. Determining the zoonotic significance of Giardia and Cryptosporidium in Australian dogs and cats. Vet. Parasitol., 154: 142-147.

Paz-e-Silva, F.M., M.M. Monobe, R.S. Lopes and J.P. Araujo Jr., 2012. Molecular characterization of Giardia duodenalis in dogs from Brazil. Parasitol. Res., 110: 325-334.

Pickerill, P.A. and L.E. Carmichael, 1972. Canine brucellosis: Control programs in commercial kennels and effect on reproduction. J. Am. Vet. Med. Assoc., 160: 1607-1615.

Rahimi E. and A. Doosti, 2012. Detection of Coxiella burnetii in poultry egg samples in Iran using nested PCR Assay. Asian J. Anim. Vet. Adv., 7: 273-276.

Rahman, M.A., M.A. Samad, M.B. Rahman and S.M.L. Kabir, 2004. Bacterio-pathological studies on salmonellosis, colibacillosis and pasteurellosis in natural and experimental infections in chickens. Bangladesh J. Vet. Med., 2: 1-8.

Ranjbar-Bahadori, S., A. Eslami and S. Bokaic, 2007. Evaluation of different methods for diagnosis of Dirofilaria immitis. Pak. J. Biol. Sci., 10: 1938-1940. 
Readel, A.M., C.A. Phillips and T.L. Goldberg, 2010. Prevalence of Salmonella in intestinal mucosal samples from free-ranging red-eared sliders (Trachemys scripta elegans) in Illinois. Herpetol. Conserv. Biol., 5: 207-213.

Refai, M., 1989. Brucellosis in animals in Egypt and its control. WHO Publication No. 25, Mediterranean Zoonoses Control Centre, pp: 1-3.

Refai, M., 2000. Control of brucellosis in animals in Egypt. Proceedings of the 2nd International Symposium Cum-Workshop of the Germany-Egypt-Region Inter-Alumni-Net, October, 2000, St. Catherine, Germany.

Rojas, P., A.M. Monahan, S. Schuller, I.S. Miller, B.K. Markey and J.E. Nally, 2010. Detection and quantification of leptospires in urine of dogs: A maintenance host for the zoonotic disease leptospirosis. Eur. J. Clin. Microbiol. Infect. Dis., 29: 1305-1309.

Roy, S., M. Roy, C.K. Asati and P. Vishwakarma, 2009. Colibacillosis in calves - its prevalence and therapeutic management. Intas. Polivet., 10: 207-211.

Ruiz, A., P. Foronda, J.F. Gonzalez, A. Guedes, N. Abreu-Acosta, J.M. Molina, and B. Valladares, 2008. Occurrence and genotype characterization of Giardia duodenalis in goat kids from the Canary Islands, Spain. Vet. Parasitol., 154: 137-141.

Schuurman, T., R.F. de Boer, E. van Zanten, K.R. van Slochteren and H.R. Scheper et al., 2007. Feasibility of a molecular screening method for detection of salmonella enterica and Campylobacter Jejuni in a routine community-based clinical microbiology laboratory. J. Clin. Microbiol., 45: 3692-3700.

Seidavi, A., S.Z. Mirhosseini, M. Shivazad, M. Chamani, A.A. Sadeghi and R. Pourseify, 2010. Detection and investigation of Escherichia coli in contents of duodenum, jejunum, ileum and cecum of broilers at different ages by PCR. As. Pac. J. Mol. Biol. Biotech., 18: $321-326$.

Sergio, D.M., E.G. Figueroa, V.G.M. Saadia, S.H. Elizabeth, R.S. Beatriz, M.A.A. Victor and J.N. Espinosa, 2012. Leptospirosis prevalence in patients with initial diagnosis of dengue. J. Trop. Med. 10.1155/2012/ 519701.

Shaikh, N., N.E. Morone, J.E. Bost and M.H. Farrell, 2008. Prevalence of urinary tract infection in childhood: A meta-analysis. Pediatric Infect. Dis. J., 27: $302-308$.
Slack, A., M. Symonds, M. Dohnt, C. Harris, D. Brookes and L. Smythe, 2007. Evaluation of a modified Taqman assay detecting pathogenic Leptospira spp. against culture and Leptospira-specific IgM enzymelinked immunosorbent assay in a clinical environment. Diagn. Microbiol. Infect. Dis., 57: $361-366$.

Smith, F.D., R. Ballantyne, E.R. Morgan and R. Wall, 2012. Estimating Lyme disease risk using pet dogs as sentinels. Comp. Immunol. Microbiol. Infect. Dis., 35: 163-167.

Sohail, F. and M.N. Sohail, 2011. L. Despite of Its weedy nature is an important medicinal plant of NWFP, Pakistan. Int. J. Pharmacol., 7: 747-748.

Sohail, F., G.M. Alam, R.R. Khan and R. Naeem, 2011 b. How to cope with dengue in developing countries like Pakistan? Asian J. Anim. Vet. Adv., 6: 1094-1124.

Sohail, M.N., A. Karim, M. Sarwar and A.M. Alhasin, 2011a. Onion (Allium cepa L.): An alternate medicine for Pakistani population. Int. J. Pharmacol., 7: 736-744.

Sohail, M.N., F. Rasul, A. Karim, U. Kanwal and I.H. Attitalla, 2011c. Plant as a source of natural antiviral agents. Asian J. Anim. Vet. Adv., 6: 1125-1152.

Strachana, N.J.C., M. MacRaeb, A. Thomsonb, O. Rotariua, I.D. Ogdenb and K.J. Forbesb. 2012. Source attribution, prevalence and enumeration of Campylobacter spp. from retail liver. Int. J. Food Microb., 153: 234-236.

Traub, R.J., T. Inpankaew, S.A. Reid, C. Sutthikornchai, Y. Sukthana, I.D. Robertson and R.C. Thompson, 2009. Transmission cycles of Giardia duodenalis in dogs and humans in Temple communities in Bangkok-a critical evaluation of its prevalence using three diagnostic tests in the field in the absence of a gold standard. Acta Trop., 111: 125-132.

Vahedi, A. and L. Vahedi, 2012. Demographics of patients with surgical and nonsurgical cystic echinococcosis inEast Azerbaijan from 2001 to 2012. Pak. J. Biol. Sci., 15: 186-191.

Vico, J.P., I. Rol, V. Garrido, B.S. Roman, M.J. Grillo and R.C. Mainar-Jaime, 2011. Salmonellosis in finishing pigs in Spain: Prevalence, antimicrobial agent susceptibilities and risk factor analysis. J. Food Prot., 74: 1070-1078.

Vignesh, S., A. Raja and R.A. James, 2011. Marine drugs: Implication and future studies. Int. J. Pharmacol., 7: $22-30$.

Wada, Y., H. Kondo, Y. Nakaoka and M. Kubo, 1996. Gastric attaching and effacing Escherichia coli lesions in a puppy with naturally occurring enteric colibacillosis and concurrent canine distemper virus infection. Vet. Pathol., 33: 717-720. 
Wasmoen, T.L., R.W. Sebring, B.M. Blumer, L.G. Chavez, H.J. Chu and W.M. Acree, 1992. Examination of Koch's postulates for Borrelia burgdorferi as the causative agent of limb/joint dysfunction in $\operatorname{dog} s$ with borreliosis. J. Am. Vet. Med. Assoc., 201: 412-418.

Widodo, G.P., E. Y. Sukandar, Sukrasno and I.K. Adnyana, 2008. A coumarin from ageratum leaves (Ageratum conyzoides L.). Int. J. Pharmacol., 4: 56-59.

Wooley, R.E. and J.L. Blue, 1976. Quantitative and bacteriological studies of urine specimens from canine and feline urinary tract infections. J. Clin. Microbiol., 4: 326-329.
Workman, S.N., G.E. Mathison and M.C. Lavoie, 2005. Pet dogs and chicken meat as reservoirs of Campylobacter species in Barbados. J. Clin. Microbiol., 43: 2642-2650.

Zhang, C., H. Wang and J. Yan, 2012. Leptospirosis prevalence in Chinese populations in the last two decades. Microbes Infect., 14: 317-323.

Zhang, F., Z. Gong, J. Zhang and Z. Liu, 2010. Prevalence of Borrelia burgdorferi sensu lato in rodents from Gansu, Northwestern China. BMCMicrobiol., Vol. 1010.1186/1471-2180-10157. 